\title{
IMPLEMENTASI MANAJEMEN SARANA DAN PRASARANA PENDIDIKAN ANAK USIA DINI
}

\author{
Siti Sofiah, Rudiyanto, Rita Mariyana \\ Universitas Pendidikan Indonesia, Jln. Setiabudhi no. 229 Bandung \\ e-mail: sofia.siti@gmail.com
}

\begin{abstract}
Abstrac : Implementation of Facilities and Infrastructure Management at the Institute of Early Childhood Education (Case Study in RA AL-Mu'min West Bandung regency). The focus of facilities and infrastructure management process is divided into subfokus planning, procurement, maintenance and supervision. Focus constraints management infrastructure constraints subfokus divided into planning, procurement, utilization, maintenance and supervision. Research is conducted qualitatively by using a single case study. This approach was Chosen in order to Obtain a natural and comprehensive data on the issue is being investigated. In this study, Researchers act as a key instrument of planning, implementing, collecting the data, analyzing, interpreting the the data and report the results. Data Obtained through (1) observation, (2) interview, and (3) documentation. Data analysis was Carried out in two stages, the time of collection and after the data collection. The analysis through the steps of data reduction, display data, and the data verification. Mechanical checking the validity of the data used to hold more diligent observation and testing triangulasi. The Reasecrh of Data analysis is then Obtained two Conclusions: (1) planning the which includes about Determining the needs of RA-related facilities and infrastructure, the determination of the required budget, Determining who Reviews those that facilitate or finance the procurement of Reviews These facilities; (2) The procurement includes: through purchase, make your own, grants, school recycling of goods that have been using; (3) maintenance covers anyone who Participated maintain infrastructure RA, then anyone who is Involved in the maintenance and how to maintain the facilities and pasarana in order to REMAIN well preserved condition (4) The supervision includes berapa how long and how Often the checks done by the school and anyone who checks the facilities and good infrastructure in RA ALMu'min West Bandung regency. All These points are unified process is implemented a management infrastructure in RA AL-Mu'min West Bandung regency.
\end{abstract}

Keywords: early childhood education institutions child, management infrastructures.

\begin{abstract}
Abstrak : Implementasi Manajemen Sarana dan Prasarana di Lembaga Pendidikan Anak Usia Dini (Studi Kasus di RA AL-Mu'min Kabupaten Bandung Barat ). Fokus penelitian ini adalah Proses manajemen sarana dan prasarana di RA AL-Mu'min Kabupaten Bandung Barat dan Kendala-kendala dalam proses manajemen sarana dan prasarana RA AL-Mu'min Kabupaten Bandung Barat. Fokus Proses manajemen sarana dan prasarana dibagi menjadi subfokus perencanaan, pengadaan, pemeliharaan dan pengawasan. Fokus kendala-kendala manajemen sarana dan prasarana dibagi menjadi subfokus kendala perencanaan, pengadaan, pendayagunaan, pemeliharaan dan pengawasan. Penelitian ini dilakukan secara kualitatif dengan menggunakan jenis penelitian studi kasus tunggal. Pendekatan ini dipilih agar dapat memperoleh data secara alami dan komprehensif mengenai masalah yang diteliti. Pada penelitian ini, peneliti bertindak sebagai instrumen kunci yang merencanakan, melaksanakan, mengumpulkan data, menganalisis, menafsirkan data
\end{abstract}


dan melaporkan hasil penelitian. Data yang diperoleh melalui (1) observasi, (2) wawancara, dan (3) dokumentasi. Analisis data dilakukan dalam dua tahap yaitu saat pengumpulan data dan setelah pengumpulan data. Analisis tersebut melalui langkahlangkah yaitu reduksi data, display data, dan verifikasi data. Teknik pengecekan keabsahan data yang digunakan adalah mengadakan pengamatan lebih tekun dan menguji triangulasi. Hasil analisis data tersebut kemudian diperoleh empat kesimpulan yaitu: (1) perencanaan yang meliputi tentang penentuan kebutuhan RA terkait sarana dan prasarana, penentuan anggaran yang dibutuhkan, penentuan siapa-siapa saja yang memfasilitasi atau membiayai pengadaan sarana tersebut ; (2) pengadaan yang meliputi :melalui pembelian, membuat sendiri, penerimaan hibah, pendaurulangan barang barang sekolah yang telah using; (3) pemeliharaan meliputi siapa saja yang ikut memelihara sarana dan prasarana RA, kemudian siapa saja yang terlibat dalam pemeliharaan beserta cara memelihara sarana dan pasarana agar tetap terjaga dengan baik kondisinya (4) pengawasan meliputi berapa lama dan berapa kali pengecekan di lakukan oleh pihak sekolah dan siapa saja yang mengecek sarana dan prasrana yang ada di RA AL-Mu'min Kabupaten Bandung Barat. Semua poin tersebut merupakan kesatuan proses manajemen sarana dan prasarana yang dilaksanakan di RA ALMu'min Kabupaten Bandung Barat.

Kata Kunci : lembaga pendidikan anak usia dini, manajemen sarana dan prasarana.

Sarana dan prasarana sekolah harus memenuhi standar minimum dalam hal ini dapat dilihat dari PERMENDIKNAS No. 24 Tahun 2007 pasal 1 menyebutkan bahwa standar sarana dan prasarana untuk sekolah mencakup kriteria minimum sarana dan kriteria minimum prasarana. Penilaian untuk akreditasi sekolah berkenaan dengan sarana dan prasarana harus memenuhi standar sarana dan prasarana minimum.

Sarana dan prasarana merupakan salah satu bagian dari manajemen yang ada di lembaga pendidikan, sarana dan prasarana mempunyai peran yang sangat penting dalam suatu organisasi, institusi ataupun lembaga pendidikan. Tanpa adanya sarana dan prasarana yang mendukung maka proses pendidikan tidak berjalan sebagaimana mestinya. Hal ini didukung oleh pendapat Mulyasa (hal 21, hlm.2004) menyebutkan bahwa sarana pendidikan merupakan peralatan dan perlengkapan yang secara langsung dipergunakan dalam menunjang proses pendidikan. Khususnya proses belajar mengajar, seperti gedung, ruang kelas, meja, kursi, serta alat-alat dan media pengajaran. Adapun prasarana pendidikan ialah fasilitas yang secara tidak langsung menunjang jalannya proses pendidikan atau pengajaran, seperti halaman, kebun, taman, jalan menuju tempat belajar, tetapi jika dimanfaatkan secara langsung untuk proses belajar mengajar, tersebut merupakan sarana pendidikan". Jumlah kelas di RA ALMu'Min berjumlah 3 kelas. 2 kelas A dan 1 kelas B. Dengan jumlah murid keseluruhan 79 orang dan jumlah guru 6 orang. Terdapat hal yang menarik sehingga saya mengambil lokasi penelitian di Raudhatul athfal ALMu'min ini karena dalam pengadaan tanah beserta bangunan gedung Raudhatul athfal banyak sekali terdapat kontribusi orang tua murid serta masyarakat sekitar dalam hal pengadaan tanah, dan bangunan karena asalnya RA ini adalah TPA yang satu atap dengan mesjid AL-Mu'min, dikarenakan mesjid akan direnovasi maka mengharuskan TPA untuk pindah lokasi terbih dahulu. Namun banyak juga masalah yang saya temui dari hasil observasi di RA ALMu'Min sangat kurang sekali perhatian pihak sekolah dalam hal sarana dan prasarana. kendala yang saya temui dalam 
hal sarana dan prasarana yang ada di RA AL-Mu'Min, diantaranya:

1. Perencanaan: keterbatasan anggaran atau dana, birokrasi bantuan pemerintah cukup rumit, kemampuan SDM dalam membuat sarana sendiri terbatas, bantuan dari pemerintah terbatas sehingga pengelola sarana dan prasarana pendidikan ditetapkan harus mengusahakan dengan cara lain, tidak ada petugas pendistribusian yang khusus menangani tentang pendistribusian barang sarana prasarana.

2. Pengadaan: kendala terkait pendanaan yang sulit sekali mendapat bantuan.

3. Inventarisasi: model dari buku inventarisasi masih dalam bentuk catatan tangan sehingga tidak membuat efisien pekerjaan sekolah, petugas inventaris merangkap sebagai pengajar.

4. Pemeliharaan: ada beberapa permainan outdoor yang belum memiliki pengaman dan tidak layak pakai sehingga perlu perhatian yang khusus.

5. Penghapusan: perusakan yang sering dilakukan oleh siswa, apabila barang merupakan barang milik pemerintah, proses penghapusannya pun cukup rumit karena harus sesuai dengan undang-undang tentang penghapusan sarana dan prasarana.

6. Tidak ada petugas khusus atau guru yang bertugas mengelola sarana dan prasarana di RA-AL Mu'Min.

\section{METODE}

Bersasarkan kecenderungan data yang di dapat dari observasi awal dan kesesuaian dengan tujuan penelitian, maka penelitian yang di ambil oleh penulis adalah penelitian kualitatif. Menurut Meleong (2007) penelitian kualitatif melakukan gambaran secara deskriptif dimana data penelitian di sajikan melalui kata-kata.
Penelitian ini dipilih karena lebih menggali, atau mengeksplorasi, mengambarkan atau mengembangkan pengetahuan bagaimana kenyataaan di alami menurut Moleong (dalam Gina, 2014. hlm 19).

Desain penelitian yang di gunakan oleh peneliti pada penelitian ini adalah studi kasus, menurut Creswell (2010) mengatakan bahwa studi Kasus adalah strategi kualitatif dimana peneliti mengkaji sebuah program, kejadian, aktivitas, proses, atau sama atau lebih individu dan aktivitas, menggunakan beragam prosedur pengumpulan data selama priode waktu tertentu.

Sehingga penelitian ini bertujuan untuk memberikan gambaran dan mengungkapkan secara intesif dan menggunakan beragam prosedur pengumpulan data selama periode tertentu yaitu tentang implementasi manajemen sarana dan prasarana pendidikan anak usia dini.

Berdasarkan pendapat di atas, penelitian kualitatif adalah penelitian yang alamiah, terbuka dan mendalam untuk mendapatkan data yang dibutuhkan baik lisan maupun tulisan untuk dideskripsikan dan dianalisis sesuai dengan tujuan penelitian.

\section{Instrumen penelitian}

Peneliti kualitatif adalah instrumen pertama penelitian. Sugiyono $(2012$, . 60) mengatakan bahwa peneliti kualitatif sebagai human instrumen, berfungsi meneptapkan focus penelitian, memilih informan sebagai sumber data, melakukan pengumpulan data, menilai kualitas data, analisi data, menafsirkan data dan membuat kesimpulan atas temuannya.

Teknik Pengumpulan Data

Dalam penlitian ini, teknik pengumpulan data ditentuan berdasarkan situasi dan kondisi yang ada di Raudhatul 
athfal AL-Mu'min Kabupaten Bandung Barat sebagai subjek dalam penelitiann ini menggunakan beberapa tektik yaitu wawancara, observasi, studi dokumentasi, dan studi literatur.

\section{HASIL DAN PEMBAHASAN}

\section{Tabel 4.6 Responden Wawancara}

\begin{tabular}{|l|l|l|l|}
\hline No & $\begin{array}{l}\text { Nama } \\
\text { Responden }\end{array}$ & Jabatan/Status & Inisial \\
\hline 1 & $\begin{array}{l}\text { Hj. Neneng } \\
\text { Sumarni, S.Pd }\end{array}$ & Kepala Sekolah & NS \\
\hline 2 & $\begin{array}{l}\text { N. Imas } \\
\text { Kurniasih }\end{array}$ & Guru & IK \\
\hline 3 & $\begin{array}{l}\text { Yani } \\
\text { Maryani, S.Pd }\end{array}$ & Guru & YM \\
\hline 4 & $\begin{array}{l}\text { Cucu } \\
\text { Cunayah }\end{array}$ & Guru & CC \\
\hline
\end{tabular}

\section{Perencanaan Sarana Dan Prasarana Di} Raudhatul Athfal AL-Mu'min

Perencanaan merupakan rancangan atau kerangka dari suatu yang akan dilakukan pada masa depan. Perencanaan sarana dan prasarana pendidikan merupakan proses perancangan upaya pembelian, penyewaan, peminjaman, penukaran, daur ulang, rekondisi/rehabilitas, distribusi atau pembuatan peralatan dan perlengkapan yang sesuai dengan kebutuhan sekolah. Mengenai proses perencanaan sarana dan prasarana. Menurut Barnawi (2012, hlm. 51) merencanakan proses perencanaan sarana dan prasarana pendidikan haruslah melibatkan unsur penting di sekolah seperti dan wakilnya, dewan guru, kepala tata usaha dan bendahara komite sekolah. Mengenai perencanaan sarana dan prasaranatemuan hasil penelitian membuktikan bahwa perencaan sarana dan prasaraa yang dilakukan oleh pihak kepala sekolah Raudhatul Athfal AL-Mu'min sudah benar adanya hal ini diperjelas oleh pernyataan Ns.

"Proses perencanaan sarana dan prasarana saya selalu mengadakan rapat terlebih dahulu dengan pihak ketua yayasan dan guru-guru tidak hanya saya yang memutuskan karena dengan hadirnya pihak-pihak terpenting dapat memberikan ide-ide dalam hal perencanaan sebelum adanya pengadaan barang dan meminimalisir kesalahan membeli barang yang tidak di perlukan fungsinya". (Hasil wawancara 16 April 2015)

Peneliti memandang bahwa suatu perencanaan menjadi hal yang sangat penting yang harus dilakukan oleh pihak sekolah. Karena dengan adanya perencaan yang matang akan menjadi pedoman dalam pelaksanaan dan pengendalian, bahkan penilaian dalam perbaikan. Oleh karena itu perencanaan sarana dan prasarana harus dilakukan dengan amat baik dan memerhatikan persyarakatan dari perencanaan yang baik. Disebutkan oleh (Depdiknas, 2009:8-9), ada beberapa persyaratan yang harus diperhatikan, sebagai berikut.

1. Perencanaan pengadaan sarana dana prasarana pendidikan harus dipandang sebagai bagian integral dari usaha peningkatan kualitas belajar mengajar.

2. Perencanaan harus jelas. Untuk hal tersebut, kejelasana suatu rencana dapat dilihat pada hal-hal berikut.

a. Tujuan dan sasaran atau target yang harus dicapai serta adanya penyusunan perkiraan biaya/harga keperluan pengadaan.

b. Jenis dan bentuk tindakan/kegiatan yang akan dilaksanakan. 
c. Petugas pelaksanaan, misal guru, karyawan dan lain-lain.

d. Bahan dan peralatan yang dibutuhkan.

e. Kapan dan dimana di laksanakam.

f. Harus diingat bahwa suatu perencanaan yang baik adalah yang realitis, artinya rencana tersebut dapat dilaksanakan

Lebih lanjut mengenai perencanaan yang dilakukan terlebih dahulu adalah penyusunan daftar kebutuhan, estimasi biaya kemudian penyusunan rencana pengadaan.

"Daftar kebutuhan di rencanakan pada awal tahun ajaran baru, saya dan pihak guru mendiskusikan sarana dan prasarana apa saja yang harus ada untuk menujang kebutuhan anak, pembelajaran, barang tidak bergerak seperti tanah dan bangunan. Tanah dan bangunan RA AL-Mu'min hibah keluarga. Asalnya tanah masih sewa dan uang sewa tanah sangat di bantu oleh orang tua murid dan pihak masyarakat. Kontribusi orang tua murid dan masyarakat sekitar amatlah besar". (Hasil wawancara 16 April 2015).

Dari hasil observasi peneliti memandang bahwa perencanaan sarana dan prasarana sudah benar adanya dan terlihat cukup baik dilaksanakan oleh pihak RA ALMu'min.

Tabel 4.5 Triangulasi dengan Tiga Teknik Pengumpulan Data Perencanaan Sarana dan Prasarana pendidikan Anak Usia Dini di RA AL-Mu'min

\begin{tabular}{|c|c|c|}
\hline Wawancara & Observasi & $\begin{array}{c}\text { Studi } \\
\text { Dokumentasi }\end{array}$ \\
\hline $\begin{array}{l}\text { Perencanaan sarana } \\
\text { dan prasarana } \\
\text { sudah berjalan }\end{array}$ & $\begin{array}{l}\text { Berdasarkan } \\
\text { hasil } \\
\text { observasi }\end{array}$ & $\begin{array}{l}\text { - } \text { perencanaa } \\
\text { n di awal } \\
\text { tahun }\end{array}$ \\
\hline
\end{tabular}

\begin{tabular}{|c|c|c|}
\hline $\begin{array}{l}\text { dengan baik sesuai } \\
\text { dengan } \\
\text { perencanaan yang } \\
\text { telah dirancang } \\
\text { sejak triwulan dan } \\
\text { tahun ajaran baru. } \\
\text { Perencanaan } \\
\text { barang bergerak } \\
\text { meliputi } \\
\text { penyusunan daftar } \\
\text { kebutuhan, estimasi } \\
\text { biaya, penyusunan } \\
\text { pengadaan. } \\
\text { Perencanaan } \\
\text { barang tidak } \\
\text { bergerak yaitu: } \\
\text { 1. Tanah } \\
\text { - Analisis } \\
\text { kebutuhan } \\
\text { - Survei tanah } \\
\text { - Survei harga } \\
\text { - Bangunan } \\
\text { Disesuaikan } \\
\text { dengan } \\
\text { jumlah } \\
\text { kebutuhan } \\
\text { ruangan dan } \\
\text { luas lahan. }\end{array}$ & $\begin{array}{l}\text { bahwa pihak } \\
\text { kepala } \\
\text { sekolah dan } \\
\text { guru telah } \\
\text { menjalankan } \\
\text { perencanaan } \\
\text { sarana dan } \\
\text { prasarana } \\
\text { sesuai dengan } \\
\text { apa yang telah } \\
\text { direncanakan } \\
\text { sejak awal. }\end{array}$ & $\begin{array}{l}\text { mengadaka } \\
\text { n rapat } \\
\text { dengan } \\
\text { pihak } \\
\text { ketuayayas } \\
\text { an beserta } \\
\text { guru-guru. } \\
\text { - Memperba } \\
\text { iki gedung } \\
\text { dan jalan } \\
\text { menuju } \\
\text { sekolah }\end{array}$ \\
\hline
\end{tabular}

Sumber: di olah oleh penulis 2015

Berdasarkan triangulasi di atas dapat ditarik garis besarnya bahwa sejauh ini pihak kepala sekolah Raudhatul Athfal ALMu'min telah melakukan dengan baik proses perencanaan prasarana langsung maupun tidak langsung. Langkah yang diambil pertama ketika perencanaan barang bergerak ialah menyusun daftar kebutuhan yang dibuat dengan cara mengidentifikasi dan menganalisis seluruh kebutuhan sekolah, dibuat dengan cara mengidentifikasi dan menganalisis kebutuhan yang akan datang, kemudian estimasi biaya dilakukan dengan cara penaksiran biaya yang dibutuhkan bagi barang yang habis dipakai, perlu ditasir atau diperkirakan dengan biaya satu bulan, triwulan dan biaya satu tahun. Kemudian rencana pengadaan dibuat kadang pertahun atau pertiwulan. Perencanaan barang tidak 
bergerak yaitu tanah dan bangunan jika tanah dilakukan dengan cara analisis kebutuhan tanah, survei tanah dan survei harga. Perencanaan bangunan disesuaikan dengan lahan yang ada dan kebutuhan bangunan.

\section{Pengadaan sarana prasarana di Raudhatul Athfal AL-Mu'min Kecamatan Bandung Barat}

Pengadaan merupakan serangkaian kegiatan menyediakan berbagai jenis sarana dan prasarana pendidikan sesuai dengan kebutuhan untuk mencapai tujuan pendidikan. Berdasarkan hasil temuan penelitian kegiatan pengadaan sarana dan prasarana di Raudhatul Athfal AL-Mu'min ini dilakukan dengan berbagai macam cara yaitu banyak menerima hibah, pembelian, serta proses daur ulang.

"Dalam hal pengadaan barang bergerak dan tidak bergerak kami banyak menerima hibah dalam hal memenuhi kebutuhan sarana dan prasarana kemudian besarnya kontribusi pihak masyarakat yang ikut membantu menyumbangkan materi dan tenaganya untuk membantu proses pengadaan sarpras". (Hasil wawancara 16 April 2015)

Salah satu keunikan yang ditemukan ketika melakukan penelitian, yaitu temuan bahwa pengadaan sarana dan prasarana di Raudhatul Athfal AL-Mu'min ini besarnya kontribusi masyarakat sekitar dan orang tua orang tua murid dalam hal pengadaan barang bergerak, tidak bergerak, maupun perbaikan sarpras yang berhubungan dengan RA. Hal tersebut bisa terjadi disebabkan terjalin baiknya komunikasi pihak RA dengan masyarakat sekitar, serta banyaknya pendekatan melalui acara non fornal yang sekolah adakan seperti pengajian rutin bersama orang tua murid dan masyarakat sekitar, serta arisan ibu-ibu. Dari acara nonrmal tersebut kepala RA menyelipkan sedikit bahasan mengenai keadaan sekolah, maka dari itu terbantunya pengadaan sarana dan prasarana Raudhatul Athfal ALMu'min. Jika hasil bantuan belum mencukupi pembelian menjadi solusi. Kemudian lanjutnya menurut guru kelompok B daun jika keadaan yang mengharuskan guru-guru membuat media pembelajaran maka yang dilakukan guru-guru RA ALMu'min adalah mendaur ulang barangbarang bekas untuk di jadikan media pemelajaran.

"Biasanya kendala sering terjadi dalam pegadaan media karena terbentur biaya, untuk menunjang pembuatan media pembelajaran. Namun barang-barang bekas menjadi penolong kami dalam hal pembuatan media pembelajaran maupun mainan yang kami persembahkan kepada anak-anak proses daur uang menjadi solusinya kami dalam pembuatan media". (Hasil Wawancara 17 April 2015)

Beberapa kegiatan yang dilakukan oleh pihak Raudhatul Athfal AL-Mu'min dalam hal pengadaan menurut Barnawi (2012, hlm. 61) penerimaan hibah merupakan cara pemenuhan kebutuhan sarana dan prasarana pendidikan dengan jalan menerima pemberian sukarela dari pihak lain. Kemudian Gunawan (2010, hlm. 44) mengungkapkan bahwa pembelian dapat dilakukan jika kondisi keuangan sekolah memang memungkinkan, cara ini merupakan cara yang sangat mudah namun, dalam pembelian hendaknya disiasati agar tidak terlalu mahal. Disamping itu pendaurulangan menurut Barnawi (2012, hlm. 62) cara pemenuhan kebutuhan sarana 
dan prasarana pendidikan dengan jalan memanfaatkan barang-barang bekas agar dapat digunakan untuk kepentingan sekolah.

Sementara itu, peneliti berpendapat bahwa proses pengadaan yang dilakukan oleh pihak RA AL-Mu'min sudah sangat baik karena banyak melibatkan pihak-pihak lain dan tangung jawab yang tinggi dari pihak kepala sekolah yang amat baik dalam hal komunikasi dengan pihak masyarakat sekitar serta orang tua murid, sehingga banyak terbantunya proses pengadaan sarana dan prasarana yang ada di RA AL-Mu'min.

\section{Tabel 4.6 Triangulasi dengan Tiga Teknik Pengumpulan Data Pengadaan Sarana dan prasarana Pendidikan Anak Usia Dini di RA AL-Mu'min}

\begin{tabular}{|c|c|c|}
\hline Wawancara & Observasi & $\begin{array}{c}\text { Studi } \\
\text { Dokumentasi }\end{array}$ \\
\hline $\begin{array}{l}\text { Berdasarkan } \\
\text { hasil } \\
\text { wawancara } \\
\text { proses } \\
\text { pengadaan } \\
\text { sarana dan } \\
\text { prasarana yang } \\
\text { ada di RA AL- } \\
\text { Mu'min } \\
\text { terdapat } \\
\text { kontribusi yang } \\
\text { besar dari } \\
\text { pihak } \\
\text { masyarakat } \\
\text { sekitar serta } \\
\text { orang tua } \\
\text { murid }\end{array}$ & $\begin{array}{l}\text { Berdasarkan } \\
\text { hasil observasi } \\
\text { atau } \\
\text { pengamatan } \\
\text { secara } \\
\text { langsung } \\
\text { terlihat bahwa } \\
\text { proses } \\
\text { pengadaan } \\
\text { bentuk dari } \\
\text { realisasi proses } \\
\text { perencanaan } \\
\text { yang telah } \\
\text { dilakukan } \\
\text { sebelumnya. }\end{array}$ & $\begin{array}{l}\text { Berdasarkan } \\
\text { data yang } \\
\text { diperoleh } \\
\text { terlihat } \\
\text { bahwa } \\
\text { proses } \\
\text { pengadaan } \\
\text { sarana dan } \\
\text { prasarana } \\
\text { banyak } \\
\text { menerima } \\
\text { hibah. }\end{array}$ \\
\hline
\end{tabular}

Sumber: Diolah oleh penulis 2015

Berdasarkan triangulasi di atas dapat ditarik kesimpulan sementara bahwa proses pengaaan sarana dan prasarana di Raudhtul Athfal AL-Mu'min dilakukan beberapa cara diantaranya pembelian, hibah dan daur ulang. Proses pengadaanpun banyak melibatkan pihak-pihak luar seperti besarnya kontribusi masyarakat sekitar dan orang tua murid. Proses pengadaan sarana dan prasaranapun merealisasikan atas perencanaan yang telah dilakukan sebelumnya. Hasil wawancara dan observasi berbanding lurus dengan hasil studi dokumentasi. Iklim warga sekolah seperti guru dan murid nyaman dan ceria sedikit banyak murid yang rajin sekolah dan semangat, antusias dalam mengikuti proses pembelajaran.

Pendayagunaan Sarana dan Prasarana Di Raudhatul Athfal ALMu'min Kecamatan Bandung Barat

Penggunaan sarana dan prsarana di sekolah merupakan tanggung jawab kepala sekolah. Namun kepala sekolah dapat melimpahkan pekerjaannya kepada wakil kepala sekolah beserta guru. Terlihat bahwa pendayagunaan yang terjadi di RA ALMu'min sangat diawasi oleh kepala sekolah. Karena berdasarkan hasil wawancara beliau menggungkap.

"Sarana dan prasarana yang ada di RA ini selalu saya ingatkan jika ada sarana yang di gunakan oleh guru ataupun murid saya selalu memberikan pengarahan untuk menyimpannya kembali di tempat semula kemudian mematuhi aturan yang ada mengenai penggunaan sarana dan prasarana apa saja yang boleh digunakan guru atau murid, jika penggunaan di ruangan kelas saya sebisa mungkin menyamaratakan sarana dan prasarana yang ada di setiap ruangan kelas". (16 April 2015)

Adapun dua prinsip penggunaan sarana dan prasarana yang harus 
diperhatikan dalam pemakaian perlengkapan pendidikan menurut (Depdiknas, 2008:42), yaitu prinsip efektifitas dan prinsip efisiensi. Prinsip efektivitas merupakan semua pemakaian perlengkapan pendidikan di sekolah harus ditujukan semata-mata dalam memperlancar pencapaian tujuan pendidikan sekolah, baik secara langsung maupun tidak langsung, sementara prinsip efisiensi berarti pemakaian semua perlengkapan yang ada tidak habis, rusak atau hilang.

Peneliti memandang bahwa itu prinsip yang disebutkan oleh Depdiknas sudah sesuai adanya dengan pendayagunaan sarana dan prasarana yang ada di Raudhatul Athfal AL-Mu'min. Karena peran kepala sekolah yang turut aktif dalam mengatur penggunaan sarana dan prasarana. Sebagaimana dikatakan oleh Herawan dan Nasihin 2011, hlm. 123) kepala sekolah harus dapat menjamin sarana dan prasarana yang digunakan seoptimal mungkin oleh warga sekolah dan agar tidak terjadi kesemrawutan dalam pengunaannya.

Namun kendala yang dihadapi oleh para guru terkadang pengunaan sarana pembelajaran yang sudah diatur jadwalnya dengan sedemikian rupa masih saja terjadi rebutan misalnya pemakaian kursi anak yang bergantian setiap minggunya yang harusnya kursi dipakai kelompok B kursi masih digunakan oleh kelompok A karena kelompok A sudah terbiasa memakai kursi. Hal tersebut terjadi dikarenakan jumlah kursi tidak sesuai dengan jumlah murid yang ada maka solusinya guru harus pintar-pintar merayu dan memberi pengertian kepada muridnya.

Tabel 4.7 Triangulasi dengan Tiga Teknik Pengumpulan Data Pendayagunaan Sarana dan

\section{prasarana Pendidikan Anak} Usia dini di RA AL-Mu'min

\begin{tabular}{|c|c|c|}
\hline Wawancara & Observasi & $\begin{array}{c}\text { Studi } \\
\text { Dokumentasi }\end{array}$ \\
\hline $\begin{array}{l}\text { Berdasarkan } \\
\text { hasil wawancara } \\
\text { pendayagunaan } \\
\text { sarana dan } \\
\text { prasarana } \\
\text { pendidikan } \\
\text { sudah sesuai } \\
\text { dengan } \\
\text { porsinya, dan } \\
\text { kepala sekolah } \\
\text { selaku orang } \\
\text { yang mengatur } \\
\text { pendayagunaan } \\
\text { sudah } \\
\text { menerapkan } \\
\text { prinsip efisien } \\
\text { dan efektivitas }\end{array}$ & $\begin{array}{l}\text { Berdasarkan } \\
\text { hasil observasi } \\
\text { terlihat bahwa } \\
\text { warga sekolah } \\
\text { memakai sarana } \\
\text { dan prasarana } \\
\text { pendidikan } \\
\text { dengan } \\
\text { memperhatikan } \\
\text { pemakaian yang } \\
\text { sesuai dengan } \\
\text { aturan yang ada, } \\
\text { kemudian } \\
\text { pemakaian } \\
\text { sarana dan } \\
\text { prasarana } \\
\text { pendidikan } \\
\text { digunakan oleh } \\
\text { guru di sekolah } \\
\text { secara hemat } \\
\text { dalam } \\
\text { pembuatan } \\
\text { media } \\
\text { pembelajaran, } \\
\text { didak mudah } \\
\text { pembelian } \\
\text { media di } \\
\text { lakukan dengan } \\
\text { memperhatikan } \\
\text { bahan dan } \\
\text { barang yang } \\
\text { dipakai. } \\
\text { man } \\
\text { maki }\end{array}$ & $\begin{array}{l}\text { Berdasarkan } \\
\text { data yang } \\
\text { didapat tidak } \\
\text { semua sarana } \\
\text { dan prasarana } \\
\text { yang ada di } \\
\text { sekolah di } \\
\text { gunakan } \\
\text { dengan baik, } \\
\text { ada saja yang } \\
\text { rusak dan } \\
\text { sekali pakai. } \\
\text { Karena ulah } \\
\text { anak yang } \\
\text { belum } \\
\text { mengerti } \\
\text { menjaga } \\
\text { sarana dan } \\
\text { prasarana } \\
\text { yang ada }\end{array}$ \\
\hline
\end{tabular}

Sumber: diolah oleh penulis 2015

Berdasarkan triangulasi di atas dapat ditarik garis besarnya bahwa pendayagunaan sarana dan prasarana pendidikan memiliki kendala dalam hal pengaturan jadwal kendala tersebut hanya bagaimana cara pihak guru dalam menangulangi masalah mengenai anak yang ingin terus 
menggunakan sarana pembelajaran terusmenerus, sedangkan jadwalnya sarana tersebut harus digunakan oleh kelompok lain. Cara penanganannya adalah bagaimana cara guru memberikan pengarahan kepada anak-anak agar mau bergantian mengguanakan sarana pembelajaran tersebut.

\section{Pengawasan Sarana Prasarana Pendidikan Anak Usia Dini Di RA Al- Mu'Min}

Pengawasan yang dilakukan oleh pihak sekolah lebih kepada pemeliharaan sarana dan prasarana karena dari waktu ke waktu sarana dan prasarana pendidikan akan mengalami penyusutan. Begitu pula yang terjadi di RA AL-Mu'min karena pemakaian sarana dan prasarana yang tiap hari gunakan padahal pihak kepala sekolah, guru maupun murid sudah diberi pengarahan agar turut ikut serta dalam proses pengawasan sarana dan prasarana Ns berpendapat mengenai pengawasan yang dilakukan di RA ALMu'min

"Pengawasan yang saya lakukan sebisa mungkin setiap hari mengecek keadaan gedung, rungan kelas, alat permainan anak di dalam ruangan maupun di ruangan, dan semua fasilitas yang menunjang bagi anak saya lakukan pengawasan sesering mungkin". (Hasil wawancara 16 April 2015)

Hal tersebut sesuai dengan yang dikemukakan oleh (Depdiknas, 2007 hlm 31-32) pengawasan sarana dan prasarana pendidikan hendaklah mencangkup untuk menjamin keselamatan orang atau siswa diperlukan pengawasan keadaan sarana dan prasarana setiap harinya. Dalam hal pengawasan sarana dan prasarana di RA ALMu'min dilakukan pengawasan rutin setiap hari dalam membersihkan kelas yang meliputi menyapu, mengepel, mengelap meja dan kursi, mengelap jendela, halaman sekolah, toilet anak dan guru. Kemudian pengawasan sarana dan prsarana secara keseluruhan dilakukan oleh pihak guru dan kepala sekolah, karena di RA ini setiap 1 bulan sekali mengadakan pelaporan sarana dan prasarana yang ada di RA.

"Pengawasan sarana prasarana yang di RA ini setiap guru dipastikan mengadakan pengecekan sarana dan prasarana baik yang bersifat primer dan skunder, setiap satu bulan sekali karena satu bulan sekali kami pihak RA Al-mu'min membantu kepala sekolah mengisi laporan bulanan, yang di laporkan kepada kantor departemen agama Kabupaten Bandung Barat. Tidak semua guru terlibat dalam hal pengecekan hanya tiap kelas satu guru yang mengecek keadaan saranan dan prasarana sekolah". (Hasil wawancara 16 April 2015)

Masalah yang sering terjadi dalam hal pengawasana sarana dan prasarana di RA AL-Mu'min cukup ironis pengrusakan sarana dan prasarana banyak sumber yang di dapat dilakukan oleh oleh siswa itu sendiri. Hal tersebut meupakan tindakan indisipliner, pengrusakan tersebut membebani anggaran sekolah karena harus menambah jumlah pengeluaran yang seharusnya tidak terjadi. Namun kendala tersebut di tangani oleh pihak guru.

"Terkadang kami lupa mengecek sarana pembelajaran yang sudah ada di tahun lalu ketika akan kami gunakan kembali di tahun berikutnya karena tidak pernah di cek hasilnya rusak tidak bisa di gunakan karena ulah tangan anak yang terkadang tidak terawasi oleh kami. Misalnya 
kusutnya benang wol yang akan di gunakan dalam menjahit gambar dengan cara sederhana sederhana, benang menjadi kusut tidak bisa di pakai lagi karena kusut dan harus di gunting". (Hasil wawncara 17April 2015).

Masalah tersebut biasanya di tangulangi oleh pihak guru dengan cara memberi pemahaman kepada anak-anak, kemudian berkaca dari pengalaman karena anak yang sangat aktif di dalam kelas. Penyimpanan sarana pembelajaran yang akan di gunakan di simpan di ruangan guru, tidak di kelas lagi. Karena pada hakikatnya anak/ siswa akan terbiasa untuk ikut serta dalam hal pemeliharaan jika terus di beri pengarahan. Pendapat tersebut sesuai dengan Barnawi (2012, hlm. 77) menumbuhkan rasa memiliki, memupuk rasa tanggung jawab, medisiplinkan, pada seluruh siswa akan menangulangi kerusakan dini pada sarana dan prasarana pendidikan yang ada di lingkugansekolah.

Peneliti memandang bahwa kendala yang terjadi saat proses pngawasan bisa ditanggulangi dengan cara pihak aparatur sekolah seprti misalnya guru melakukan pemeliharaan dengan tepat. Kemudian tidak menunda-nunda untuk memperbaiki sarana dan prasarana yang rusak. Kemungkinan besar faktor-faktor penyebab kerusakan tersebut akan tertangulangi.

\section{Tabel 4.7 Triangulasi Dengan Tiga Teknik Pengumpulan Data Pengawasan Sarana dan Prasarana Pendidikan Anak Usia Dini Di RA AL-Mu'min}

\begin{tabular}{|l|l|l|}
\hline \multicolumn{1}{|c|}{ Wawancara } & \multicolumn{1}{|c|}{ Observasi } & \multicolumn{1}{c|}{$\begin{array}{c}\text { Studi } \\
\text { Dokumentasi }\end{array}$} \\
\hline $\begin{array}{l}\text { Berdasarkan } \\
\text { hasil }\end{array}$ & $\begin{array}{l}\text { Berdasarkan } \\
\text { hasil observasi }\end{array}$ & $\begin{array}{l}\text { Berdasarkan } \\
\text { data yang }\end{array}$ \\
\hline
\end{tabular}

\begin{tabular}{|c|c|c|}
\hline $\begin{array}{l}\text { wawancara } \\
\text { pengawasan } \\
\text { sarana dan } \\
\text { prasarana } \\
\text { pendidikan di } \\
\text { lakukan secara } \\
\text { rutin, dan } \\
\text { pengawasan } \\
\text { keseluruhan } \\
\text { sarana dan } \\
\text { prasarana yg } \\
\text { ada di RA AL- } \\
\text { Mu'min selalu } \\
\text { di lakukan } \\
\text { kegiatan } \\
\text { pelaporan } \\
\text { setiap tiga } \\
\text { bulan sekali ke } \\
\text { pada pihak } \\
\text { DEPAG }\end{array}$ & $\begin{array}{l}\text { Pengawasan } \\
\text { yang di lakukan } \\
\text { setiap harinya } \\
\text { oleh pihak } \\
\text { kepala sekolah, } \\
\text { memeriksa } \\
\text { gedung sekolah } \\
\text { sampai kepada } \\
\text { media } \\
\text { pembelajaran } \\
\text { anak didik. } \\
\text { Kemudian guru- } \\
\text { guru yang selalu } \\
\text { aktif dalam } \\
\text { pengawasan } \\
\text { sarana dan } \\
\text { prasarana setiap } \\
\text { harinya } \\
\text { kemudian ikut } \\
\text { sertanya dalam } \\
\text { membantu } \\
\text { kepala sekolah } \\
\text { dalam hal } \\
\text { pelaporan } \\
\text { sarana dan } \\
\text { prasarana } \\
\text { pendidikan. }\end{array}$ & $\begin{array}{l}\text { didapat pihak } \\
\text { sekolah rutin } \\
\text { selama tiga } \\
\text { bulan sekali } \\
\text { melakukan } \\
\text { pengawasan } \\
\text { keseluruhan } \\
\text { terhadap sarana } \\
\text { dan prasarana } \\
\text { pendidikan dan } \\
\text { melaporkan } \\
\text { hasil } \\
\text { pengawasan } \\
\text { tersebut kepada } \\
\text { pihak DEPAG. }\end{array}$ \\
\hline
\end{tabular}

Sumber: diolah oleh penulis 2015

Berdasarkan triangulasi diatas dapat ditarik kesimpulan sementara bahwa upaya pengawasana sarana dan prasarana (gedung sekolah, ruangan kelas, toilet serta media pembelajaran)di lakukan secara rutin yaitu dalam kurun waktu tiap hari oleh pihak kepala sekolah dan pihak guru, kemudian sarana prasarana keseluruhan di lakukan pengawasan setiap bulan dan laporan hasil pengawasan diberikan kepada DEPAG.

\section{SIMPULAN}

Berdasarkan hasil penelitian dalam menjawab rumusan masalah dan tujuan penelitian, maka data penelitian menghasilkan beberapa kesimpulan, yaitu:

1. Perencanaan sarana dan prasarana pendidikan yang di lakukan oleh pihak 
Raudhatul Athfal AL-Mu'min tahap awal adalah melakukan proses perancangan upaya pembelian, jika dana yang sudah disiapkan oleh pihak yayasan kemudian sebagian dana dari iyuran bulanan. Dari hasil pengumpulan dana tersebut barulah dapat di rencanakan apa saja yang bisa di beli dan yang tidak. Kedua proses daur ulang/pembuatan sendiri, proses ini di rencanakan jika keadaan sarana dan prasarana masih dapat di lakukan guru atau kepala sekolah dalam memperbaiki/menganti sarana dan prasarana yang sudah dalam keadaan kurang baik, proses daur ulang sering di lakukan dalam hal membuat media pembelajaran. Kemudian selanjutnya yaitu pembuatan peralatan secara mandiri proses ini hampir sama dengan proses daur ulang lebih memanfaatkan bahan barang-barang bekas untuk mendapatkan media pembelajaran, maupun alat permainanan yang dapat anak gunakan. Proses-proses tersebut banyak melibatkan unsur-unsur penting di sekolah seperti ketua yayasan, kepala sekolah,guru-guru serta ketua komite . Proses tersebut banyak melibatkan unsur penting di sekolah dimaksudkan untuk membuka masukan dari berbagai pihak dan meningkatkan kematangan dari sebuah rencana, karena dengan perencanaan yang matang dapat meminimalisir kemungkinan terjadi kesalahan dalam meningkatkan efektivitas dan efisiendi pengadaan sarana dan prasarana.

2. Pengadaan sarana dan prasarana banyak melibatkan pihak-pihak luar sekolah seperti besarnya kontribusi dari warga sekitar dan orang tua murid. Pengadaan tanah pada awalnya masih sewa, kemudian dana sewa tanah sebagian berasal dari warga sekitar serta orang tua murid. Hal tersebut terjadi karena sangat baiknya komunikasi pihak kepala sekolah dengan orang tua murid dan warga sekita, biasanya sekolah mengadakan acara nonformal seperti pengajian setiap sebulan sekali, atau arisan. Dan di sela-sela acara di dalam pembahasan biasanya kepala sekolah sedikit membahas mengenai keadaan sekolah. Kemudian dari pembahasan sekilas tersebutlah terbentuknya masyarakat dan pihak orang tua murid yang memiliki kesadaran untuk banyak berkontribusi dalam hal pengadaan sarana dan prasarana pendidikan di RA AL-Mu'min.

3. Penggunaan sarana dan prasarana pendidikan di RA AL-Mu'min menggunakan prinsip "prinsip efektivitas dan efisiensi". Efektivitas berarti semua pemakaian perlengkapan pendidikan di sekolah ditujukan semata-mata dalam memperlancar pencapaian tujuan pendidikan sekolah. Kemudian Efesiensi pemakaian semua perlengkapan sarana dan prasarana pendidikan secara hemat dan hati-hati, namun kendala yang muncul adalah ketika sarana dan prasarana tidak selamanya dalam keadaan baik dan rusak jadi mau tidak mau harus menggantinya dengan yang baru. Namun dalam hal pengadaan yang baru kepala sekolah mendahulukan yang sekiranya sangat dibutuhkan maka sarana dan prasarana itulah yang didahulukan pengadaannya. Dalam hal penggunaan sarana dan prasarana kepala sekolah turut berperan aktif dan bertanggung jawab dalam menjamin sarana dan prasarana yang ada di sekolah, dan mengontrol penggunaaan sarana dan prasarana agar seoptimal mungkin digunakan oleh personil sekolah. 
4. Pihak RA AL-Mu'min melakukan pemantauan kondisi sarana dan prasarana yang ada secara rutin. Pihak kepala sekolah RA AL-Mu'min segera melakukan perbaikan atau mengadakan sarana prasaran yang dibutuhkan oleh siswa maupun pihak guru melalui pengajuan usulan kepada Ketua yayasan untuk melengkapi kebutuhan sarana dan prasarana yang di butuhkan. Kemudian kepala sekolah dan pihak guru mempunyai kegiatan rutin membuat laporan perbulan dan persemester melaporkan keadaan sarana dan prasarana yang ada di RA AL-Mu'min kepada pihak DEPAG.

\section{DAFTAR PUSTAKA}

Barnawi. (2012). Manajemen Sarana dan Prasarana Sekolah. Yogjakarta: Aaruzz Media.

Creswell, JW. (2010). Reseach Design Pendekatan Kualitatif, Kuantitatif, dan Mixed. Yogyakarta: Pustaka Pelajar.

Gunawan, A. H. (2005). Administrasi Sekolah (Administrasi Pendidikan Micro). Jakarta: PT. Rineka Cipta.

Herawan, E. (2004). Peningkatan Manajemen Sekolah Dasar. Jakarta: PT. Bumi Akasara.

Meleong, J. L. (2012). Metodologi Penelitian Kualitatif. Bandung: PT. Remaja Rosda Karya.

Mulyasa, E. (2007). Menjadi Kepala Sekolah Profesional. Bandung: PT Remaja Rosda karya.

Peraturan Menteri Pendidikan Nasional Republik Indonesia Nomor 24 Tahun 2007 tentang Standar Sarana dan Prasarana Pendidikan.

Sugiyono. (2012). Memahami Penelitian Kualitatif. Bandung: Alfabeta.
Depdiknas. (2008). Kurikulum Tingkat Satuan Pendidikan. Jakarta: Dikmenum. Depdiknas.

Permendiknas Nomor 19 Tahun 2007 tentang Standar Pengelolaan PendidikanOleh Satuan Pendidikan Dasar dan Menengah. Jakarta: Depdiknas

Depdiknas. (2009). Kurikulum Tingkat Satuan Pendidikan. Jakarta: Pusat Kurikulum, Balitbang Depdiknas 